\title{
A short introduction to historical earthquakes in Libya
}

\author{
Abdunnur S. Suleiman $\left({ }^{1}\right)$, Paola Albini $\left({ }^{2}\right)$ and Paola Migliavacca $\left({ }^{2}\right)$ \\ $\left.{ }^{1}\right)$ Geophysics Department, Faculty of Science, Al-Fateh University, Tripoli, Libya \\ ${ }^{(2)}$ Istituto Nazionale di Geofisica e Vulcanologia, Sezione di Milano, Italy
}

\begin{abstract}
As a result of the relative motion of the African and European plates, Libya, located at the north central margin of the African continent, has experienced a considerable intraplate tectonism, particularly in its northern coastal regions. If the seismic activity of the last fifty years, at most, is known from instrumental recording, macroseismic effects of those earthquakes which affected Libya in the past centuries are still imperfectly known. To try and partly overcome this lack of information, in this contribution we present a short introduction to historical earthquakes in Libya, focusing on the period up to 1935. According to the studies published in the last twenty years, the earliest records of earthquakes in Libya are documented in the Roman period (3rd and 4th century A.D.). There is a gap in information along the Middle and Modern Ages, while the 19th and early 20th century evidence is concentrated on effects in Tripoli, in the western part of nowadays Libya. The Hun Graben area (western part of the Gulf of Sirt) has been identified as the location of many earthquakes affecting Libya, and it is in this area that the 19 April 1935 earthquake $\left(M_{w}=7.1\right)$ struck, followed by many aftershocks. Further investigations are needed, and some hints are here given at historical sources potentially reporting on earthquake effects in Libya. Their investigation could result in the needed improvement to lay the foundations of a database and a catalogue of the historical seismicity of Libya.
\end{abstract}

Key words Libya-historical seismicity

\section{Introduction}

The complex pattern of deformation between Eurasia and Africa, the corresponding plate motions and underlying driving forces, lead to strong variations in seismic hazard throughout the region. Libya, located at the north central margin of the African continent, has experienced a considerable intraplate tectonism particularly in its northern coastal regions. The information on the seismicity related to the seismotectonic setting of this region mostly relies upon the data from in-

Mailing address: Dr. Suleiman Abdunnur, Faculty of Science, Al-Fateh University, P.O. Box 13044, Tripoli, Libya; e-mail: abdunnur_s@hotmail.com strumental recording, and the historical earthquakes of the past are scarcely known (fig. 1).

Although the authors are aware that compiling a uniform catalogue of the earthquakes known to have affected Libya in the past centuries is a priority, and especially for seismic hazard assessment purposes, this article is simply an overview of the studies available to date on historical earthquakes in Libya, as the basis for establishing an international collaboration in this field.

The earthquakes which affected Libya up to 1935, though not necessarily located in this country, are presented through a summary of the available information and with a specific reference to the most recent critical interpretation offered by a few studies published in the last twenty years. The most important earthquakes considered by the aforementioned studies are listed according to two time frames, up 


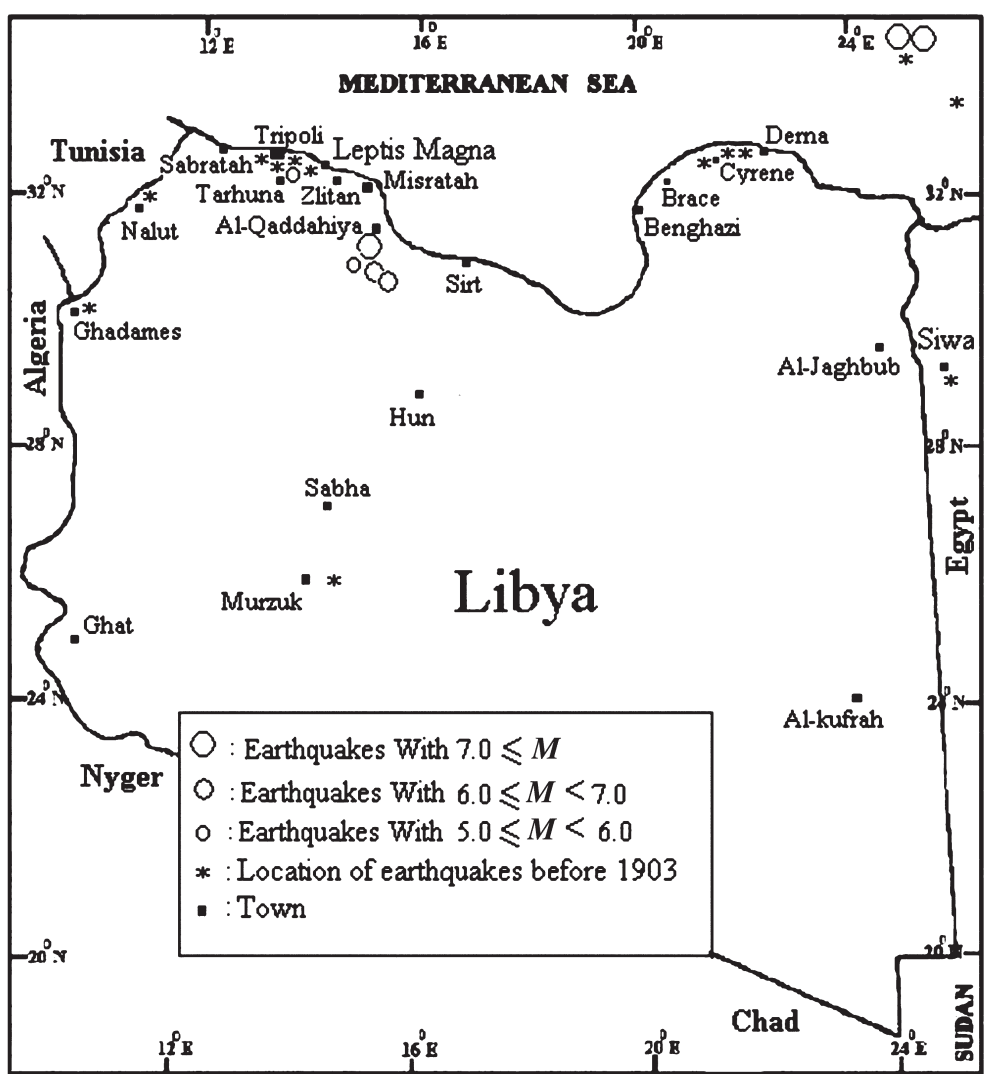

Fig. 1. Seismicity of Libya from the Antiquity to 1935 . Note that the city of Brace is today Al-Maraj and Cyrene is today Shahat.

to 1900 (table I) and from 1901 to 1935 (table II). Their location is shown in fig. 1.

After short considerations on these studies, the results of sample investigations and some suggestions on potential sources possibly dealing with earthquake effects in Libya are proposed.

\section{Modern studies of past Libyan earthquakes}

Only recently the past seismicity of Libya attracted the interest of the researchers. According to our review of the studies produced in the last twenty years, the most studied earthquakes are those occurred in the 3rd and 4th centuries (table I) and in the early 20th century (table II).

Some contributions dealing with earthquakes affecting Libya in the Antiquity relied upon historical data, while others used both historical and archaeological data. In particular, the 262 A.D. earthquake, which is considered to have affected Cyrene, is described only according to the historical data (Guidoboni, 1989; Guidoboni et al., 1994; Ambraseys, 1994; Ambraseys et al., 1994). The archaeological data supplied the most relevant information on an earthquake that caused damage in Tripolitania in 306 or 310 (Polidori et al., 1999) and two other earthquakes in Cyrenaica between 361 and June 363 (Guidoboni et al., 1994) and at the end of the 4th century 
Table I. Earthquake effects in Libya up to 1900 according to the studies published in the last twenty years $(D=$ damage; $F=$ felt $)$.

\begin{tabular}{|c|c|c|c|c|}
\hline Date & $\begin{array}{l}\text { Area of origin and } \\
\text { Libyan affected places }\end{array}$ & $\begin{array}{l}\text { Level of } \\
\text { effects }\end{array}$ & Study & Comments \\
\hline \multirow[t]{2}{*}{262 A.D. } & $\begin{array}{l}\text { Libya? } \\
\text { Cyrene }\end{array}$ & $D$ & $\begin{array}{l}\text { Guidoboni (1989) } \\
\text { Guidoboni et al. (1994) }\end{array}$ & Historical data \\
\hline & $\begin{array}{l}\text { Libya? } \\
\text { Cyrene }\end{array}$ & $D$ & $\begin{array}{l}\text { Ambraseys et al. (1994) } \\
\text { Ambraseys (1994) }\end{array}$ & Historical data \\
\hline 306 to 310 & $\begin{array}{l}\text { Libya? } \\
\text { Leptis Magna, Sabratha }\end{array}$ & $D$ & Polidori et al., 1999 & $\begin{array}{l}\text { Archaeological and } \\
\text { historical data }\end{array}$ \\
\hline 361-June 363 & $\begin{array}{l}\text { Libya? } \\
\text { Cyrene, Balagrae }\end{array}$ & $D$ & Guidoboni et al. (1994) & $\begin{array}{l}\text { Archaeological and } \\
\text { historical data }\end{array}$ \\
\hline \multirow[t]{5}{*}{365} & $\begin{array}{l}\text { North of Creta } \\
\text { Libya }\end{array}$ & $D$ & $\begin{array}{l}\text { Guidoboni (1989) } \\
\text { Guidoboni et al. (1994) }\end{array}$ & $\begin{array}{l}\text { Archaeological and } \\
\text { historical data }\end{array}$ \\
\hline & Leptis Magna, Sabratha & $D$ & $\begin{array}{l}\text { Di Vita (1995) } \\
\text { Polidori et al. (1999) }\end{array}$ & $\begin{array}{l}\text { Archaeological and } \\
\text { historical data }\end{array}$ \\
\hline & Hellenic Arc Cyrenaica & $D$ & Ambraseys et al. (1994) & Historical data \\
\hline & $\begin{array}{l}\text { Hellenic Arc } \\
\text { Apollonia, Balagrai, } \\
\text { Cyrene, Hydrax, Setif }\end{array}$ & $D$ & Ambraseys (1994) & Historical data \\
\hline & $\begin{array}{l}\text { Hellenic Arc } \\
\text { Leptis Magna, } \\
\text { Sabratha, } \\
\text { Balagrae, Cyrene, } \\
\text { Ptolemais }\end{array}$ & & Stiros (2001) & $\begin{array}{l}\text { Archaeological and } \\
\text { historical data }\end{array}$ \\
\hline End of 4th century & $\begin{array}{l}\text { Libya? } \\
\text { Cyrene, Hydrax }\end{array}$ & $D$ & $\begin{array}{l}\text { Guidoboni et al. (1994) } \\
\text { Bacchielli (1995) }\end{array}$ & $\begin{array}{l}\text { Archaeological and } \\
\text { historical data }\end{array}$ \\
\hline 704 and/or 742 & «spurious» & - & $\begin{array}{l}\text { Ambraseys (1984) } \\
\text { Ambraseys et al. (1994) }\end{array}$ & Mislocated in Libya \\
\hline 1183 & «spurious» & - & Ambraseys (1984) & $\begin{array}{l}\text { Tripoli in Syria (today } \\
\text { in Lebanon), damaged } \\
\text { by the } 1170 \text { earthquake, } \\
\text { interpreted as Tripoli in } \\
\text { Libya }\end{array}$ \\
\hline 1656 & $\begin{array}{l}\text { Libya } \\
\text { Tripoli }\end{array}$ & $D$ & $\begin{array}{l}\text { Ambraseys (1984) } \\
\text { Ambraseys et al. (1994) }\end{array}$ & \\
\hline 1803 & $\begin{array}{l}\text { Libya? } \\
\text { Tripoli }\end{array}$ & $F$ & Ambraseys et al. (1994) & $\begin{array}{l}\text { Probably a duplication } \\
\text { of the } 1903 \text { earthquake } \\
\text { (see table II, this study) }\end{array}$ \\
\hline 1811 & $\begin{array}{l}\text { Egypt } \\
\text { Libyan desert near Siwa }\end{array}$ & $F$ & Ambraseys et al. (1994) & \\
\hline 5 August 1853 & $\begin{array}{l}\text { Libya } \\
\text { Murzuq (Fezzan) }\end{array}$ & $F$ & Ambraseys et al. (1994) & \\
\hline 22 December 1860 & $\begin{array}{l}\text { Libya } \\
\text { border with Tunisia }\end{array}$ & $F$ & Ambraseys et al. (1994) & \\
\hline 24 June 1870 & $\begin{array}{l}\text { Eastern Mediterranean } \\
\text { Benghazi }\end{array}$ & $F$ & Ambraseys et al. (1994) & \\
\hline August 1883 & $\begin{array}{l}\text { Libya } \\
\text { Ghadàmes }\end{array}$ & $D$ & $\begin{array}{l}\text { Ambraseys (1984) } \\
\text { Ambraseys et al. (1994) }\end{array}$ & \\
\hline
\end{tabular}




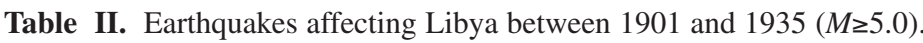

\begin{tabular}{|c|c|c|c|}
\hline Date & $\begin{array}{l}\text { Area of origin } \\
\text { and Libyan } \\
\text { affected places }\end{array}$ & Study & Magnitude \\
\hline 22 November 1903 & $\begin{array}{l}\text { Libya } \\
\text { Tripoli } \\
\text { - region of Tarhuna }\end{array}$ & $\begin{array}{c}\text { Ambraseys (1984) } \\
\text { Ambraseys et al. (1994) }\end{array}$ & $5.0(2)$ \\
\hline 2 February 1907 & - & - & $\begin{array}{l}5.8(1) \\
5.8(2) \\
5.8(3)\end{array}$ \\
\hline 18 May 1914 & $\begin{array}{l}\text { Libya } \\
\text { Al Qaddahiyah }\end{array}$ & $\begin{array}{c}\text { Ambraseys (1984) } \\
\text { Ambraseys et al. (1994) }\end{array}$ & $\begin{array}{l}5.1(1) \\
5.0(2)\end{array}$ \\
\hline 14 October 1918 & - & - & $\begin{array}{l}5.4(2) \\
5.4(3)\end{array}$ \\
\hline 26 June 1926 & $\begin{array}{l}\text { Hellenic Arc } \\
\text { North Libya }\end{array}$ & Ambraseys et al. (1994) & $7.1(2)$ \\
\hline 30 August 1926 & $\begin{array}{l}\text { Hellenic Arc } \\
-\end{array}$ & Ambraseys et al. (1994) & $7.4(2)$ \\
\hline \multirow[t]{2}{*}{$\begin{array}{l}\text { 19 April } 1935 \\
\text { 15.23 GMT }\end{array}$} & $\begin{array}{l}\text { Western Gulf of Sirt } \\
\text { Damage at: } \\
\text { Al Qaddahiya } \\
\text { Bu Njaim } \\
\text { Buayrat al Hsun } \\
\text { Zlitan } \\
\text { Misratah } \\
\text { Bani Walid } \\
\text { Zillah } \\
\text { Sirt } \\
\text { Tripoli }\end{array}$ & Ambraseys (1984) & $\begin{array}{l}7.0(1) \\
7.0(2) \\
7.0(3) \\
6.9(4)\end{array}$ \\
\hline & $\begin{array}{l}\text { Al Qaddahiya - } \\
\text { Bu Njaim area }\end{array}$ & Suleimann and Doser (1995) & \\
\hline $\begin{array}{l}\text { 19 April } 1935 \\
\text { 20.31 GMT }\end{array}$ & $\begin{array}{l}\text { Al Qaddahiya - } \\
\text { Bu Njaim area }\end{array}$ & Suleimann and Doser (1995) & $\begin{array}{l}5.7(1) \\
5.6(2) \\
5.6(3) \\
6.4(4)\end{array}$ \\
\hline $\begin{array}{l}\text { 20 April } 1935 \\
\text { 05.10 GMT }\end{array}$ & $\begin{array}{l}\text { Al Qaddahiya - } \\
\text { Bu Njaim area }\end{array}$ & Suleimann and Doser (1995) & $\begin{array}{l}6.2(1) \\
6.1(2) \\
6.1(3) \\
6.4(4)\end{array}$ \\
\hline
\end{tabular}

(1) $M_{s}$ from Ambraseys (1984), table 1; (2) $M_{s}$ from Ambraseys et al. (1994), table 3.1; (3) $M_{s}$ from Ambraseys (1994), table 1; (4) $M_{w}$ from Suleimann and Doser (1995), table 3.

(Guidoboni et al., 1994; Bacchielli, 1995). For these two earthquakes, the available studies only mention the places affected in Libyan territory, while their epicentral area is considered difficult to assess at this stage.

On the other hand, there is a good agreement on the fact that the 365 A.D. earthquake originated in the Hellenic Arc among the several studies who dealt with this large, Mediterranean event. For what Libya's territory is concerned, table I list the main studies describing damage either to both Tripolitania and Cyrenaica (Guidoboni, 1989; Guidoboni et al., 1994; Di Vita, 1999; Stiros, 2001) or to Tripoli- 
tania only (Polidori et al., 1999) or mainly to Cyrenaica (Ambraseys, 1994; Ambraseys et al., 1994).

The mentioned studies thoroughly discussed both the provenance and reliability of historical and archaeological data they used, and to them we address the reader for details. Here it is only worth mentioning that there are very few reliable written records testifying to earthquake effects in the territory of Libya in this early period, namely those related to the 262 and 365 events, and even these are very generic in nature.

There is only the study by Ambraseys (1984) dealing with the seismicity of Tripolitania from Antiquity to mid 20th century. Between the 5 th to mid 17 th century, the effects of two earthquakes only were related either to the whole of Libya (704 A.D.) or to Tripoli (1183) (table I). For both, Ambraseys (1984) concluded that they were mislocated or the records misinterpreted. In both cases, the information comes from Sieberg (1932a,b). The reliability of Sieberg's lists of earthquakes has been discussed on other occasions for which his list was the only evidence, the main criticism being that he did not supply precise references for his statements, making it impossible to trace back and verify the actual records he used.

Between mid 17th and late 19th century, the available studies supply information on a 1656 event affecting Tripoli, and on six 19th century earthquakes with moderate effects in Libya (Ambraseys, 1984; Ambraseys et al., 1994). Few words on the 1656 earthquake, which is considered as having affected Tripoli on the basis of the evidence supplied by a later seismological compilation (Dresdnissche Geleherte Anzeigen, 1756), mentioning «die Stadt Tripoli in der Barbaren» (the town of Tripoli in the Barbary States). Two centuries after the earthquake, von Hoff (1840) wrongly associated this earthquake with Tripoli in Syria (today Lebanon), and since then this event is uncritically located by earthquake catalogues in the Middle East instead of in Libya.

For the sake of completeness, earthquake effects in Libyan territory from the Antiquity to the 20th century are included in Ambraseys (1994) and Ambraseys et al. (1994).
Since the advent of instrumental recording, a large number of earthquakes have been recorded in Libya and its offshore region. Figure 1 includes the epicentres of these earthquakes for the period 1901-1935 according to the locations proposed by the studies in table II.

Studies on this period concern more the interpretation of instrumental recordings than macroseismic effects (e.g. Suleiman and Doser, 1995). There is the only exception of Ambraseys (1984) and the information he gathered on the 1935 earthquake in the western part of the Gulf of Sirt. He listed ten damaged places in Libya (table II) and about twenty more places in Libya and Tunisia where the earthquake was felt; macroseismic effects were found in unpublished sources and reported by «residents in Tripolitania at the time of the earthquake».

\section{Sample investigations for macroseismic evidence}

The following case histories show the outcome of sample investigations for macroseismic evidence of known and unknown past earthquakes in Libya, looked for in Italian sources. They are meant to introduce the suggestions on potential historical sources proposed in the following section.

\subsection{An unknown 17th century earthquake at Tripoli, Libya?}

Mention of the 25 May 1685 earthquake appears for the first time in this study. It was retrieved through the bibliography on Libya by Minutilli (1903) and the reference given by Bono (1982). The flysheet (fig. 2) contained an anonymous letter sent from Tripoli to a merchant in Ancona in which, together with other phenomena and events, there is the following description of an earthquake (Anonymous, 1685):

«Sul fare del giorno [24 May] si cominciò ad oscurar talmente, che pareva si fosse mutato da giorno in notte, e poi venne una gran pioggia accompagnata da terribilissima tempesta, che ruppe tutti li tetti delle Case, e uccise più di cinque mila di quei barbaricani, con la 


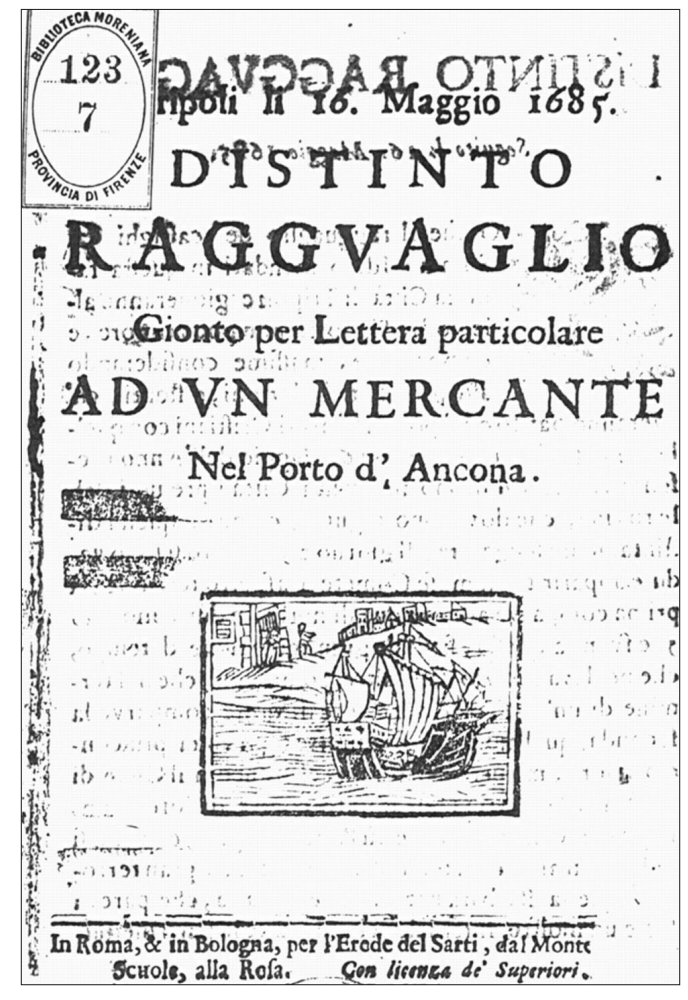

Fig. 2. First page of the flysheet describing the 25 May 1685 eartquake at Tripoli, Lybia.

morte di tutti li bestiami, che si ritrovavano in campagna. Il giorno seguente [25 May] abbaté il Terremoto più di 200 Case, e frà queste le tre più famose moschee che soliti orare questi Maometani ... (On the beginning of the day [24 May] it became so dark, that it seemed that day had changed into night, and then a heavy rainfall came together with hail, and all the roofs were broken, and more than five thousand barbarians died, and the livestock as well, in the country. On the day after [25 May] the earthquake made more than 200 buildings collapse, and among them the three most famous mosques where the Muslims used to pray)».

The whole letter sounds emphatic, and verging on exaggeration. At this stage, there are no other independent sources available on this earthquake, as well as no substantial elements to doubt of the truthfulness of this record (on this point see Bono, 1982). In particular, this record does not coincide with information on any event that affected Tripoli in Syria (today Lebanon) in 1685. Anyway, the uniqueness of the available source suggests that further evidence is needed to link without any doubt this record with Tripoli in Libya.

\subsection{An Italian source on the 1883 earthquake, Ghadàmes}

Concerning the effects of the 1883 event affecting the oasis of Ghadàmes and surroundings (south-western part of Libya), an anonymous note that appeared in an Italian geographical journal has been retrieved (Anonymous, 1884). It contained a summary of a report sent to an equivalent French journal (Comptes-Rendus de la Societé Géographique) by Duveyrier (1883), who is the source mentioned by Ambraseys et al. (1994). In his turn, Duveyrier had received the information through a letter by «Qâsem ben Mûsê ben el Hâg' Mohamed el Ghedâmesi», dated Tripoli, 8 October 1883 . From the date given according to the Libyan use, «end of the month of Chawâl» the earthquake could be dated in the Gregorian calendar «between $23 \mathrm{Au}-$ gust and 2 September 1883» (Duveyrier, 1883 as reported by Anonymous, 1884).

\subsection{Looking for macroseismic effects of the 1926 and 1935 earthquakes}

These two earthquakes differ from each other for having the 1926 origin in the Hellenic Arc and the 1935 for being the largest 20th century instrumentally recorded earthquake with epicentre located inside Libya's territory (see table II for magnitude estimates). In that period, Libya was under Italian domination, and this is the main reason for a supplement of investigation in Italian records on these early 20th century earthquakes.

A new piece of information on the Hellenic Arc earthquake of 30 August 1926 was retrieved. Two seismological bulletins published at the time in Italy (Cavasino, 1927; Ingrao, 
1930) under the section devoted to «Colonie Italiane» (Italian colonies) report that on 12:40 of the 30 August 1926 at Benghazi and Derna an earthquake was felt and an intensity of the IV degree according to the Mercalli macroseismic scale was assessed. The intensity is in this case higher than that reported at Tripoli and Benghazi for the 26 June 1926 event (II-III for both places) (see table II). Unfortunately, no more details are given.

On 19 April 1935, at 15.23 GMT, a large earthquake $\left(M_{w}=7.1\right.$, according to Suleiman and Doser, 1995; $M_{s}=7.0$ according to Ambraseys, 1994) hit the Hun Graben area near the city of Al-Qaddahiya, in the western part of the Gulf of Sirt. It was followed by a large number of aftershocks, two with $M_{w} 6.4$ (Suleiman and Doser, 1995), which occurred respectively five hours later on 19 April, and in the early morning of 20 April. People all over the country felt this earthquake and the year 1935 was remembered as the "year of the shock».

Libya being at that time under Italian rule, a sample investigation has been carried out in the the Italian press, looking for reports on this earthquake. One of the main Italian newspaper published at that time, the «Corriere della Sera», though supplying information on earthquakes in other parts of the world, and accurately describing the visit of Umberto, Prince of Savoy, and his wife to Tripoli and Ghadàmes at the end of April 1935 (Corriere della Sera, 1935c), does not mention any earthquake effects in Libya. Censorship of disasters affecting the «Italian territory» was common in that period, and is confirmed by the fact that in the 20 April issue (Corriere della Sera, 1935a) the generic information of a distant earthquake was in fact reported: "Un terremoto catastrofico a $1500 \mathrm{~km}$. registrato dall'Osservatorio Ximeniano - Padre Guido Alfani ... comunica: Nel pomeriggio, alle 16.23'30”, tutti gli strumenti sismici dell'Osservatorio hanno iniziato la registrazione di un terremoto lontano. ... La distanza della località colpita non risulta molto grande perché s'aggira sui 1500 chilometri ... Stando tuttavia ad alcuni indizi e con tutte le riserve, sembrerebbe non potersi escludere che si tratti di un terremoto di origine sud-orientale» (A catastrophic earthquake at a distance of $1500 \mathrm{~km}$ recorded by the Osservatorio $\mathrm{Xi}$ meniano [in Florence] - Father Guido Alfani says: In the afternoon, at $16.23^{\prime} 30^{\prime \prime}$, all the seismic instruments of the Observatory started the recording of a distant earthquake ... The distance from the affected place is not so large because it is about $1500 \mathrm{~km}$. From some hints and with many doubts, it seems it cannot be excluded that it was an earthquake originated in the South-East. Time and distance are in due coherence with an epicentral location in Libya, but in the following days the news is disregarded and details on a damaging earthquake in Taiwan («Formosa») is reported instead (Corriere della Sera, 1935b).

A few pieces of information are given by the coeval seismological bulletins published by the «Società Sismologica Italiana» (Agamennone, $1935)$ and by the $« R$. Ufficio Centrale di Meteorologia e Geofisica» (Cavasino, 1937). The latter reported that:

«On the 19th of April 1935, at 16h and 25m at Tripoli an earthquake was felt. The macroseismic intensity was VI according to the Mercalli scale. Its epicentre, according to the Seismological Office in Strasbourg, is in the sea, in front of the Cape Misurata ... The same shock was felt in Eastern Sicily and more lightly in Apulia» (originally in Italian, translated by the authors) (Cavasino, 1937).

\section{Potential historical sources on Libya's past earthquakes}

From the overview supplied in the previous sections and tables, it is clear that our knowledge of earthquakes in Libya between the 3rd century A.D. and 1935 relies to date on a meagre set of historical records. The historical and geographical reasons that could account for the silent periods highlighted in our overview have to be found and pointed out as clearly as possible when preparing a feasibility study aiming at collecting new data on past earthquakes in Libya.

For instance, there is an indisputable concentration of information in the flourishing period (3rd and 4th century) of the main urban settlements of Phoenician and Greek origins 
along the coast of Tripolitania and Cyrenaica. This information derives mostly from studies using archaeological data, and the time-span it covers ends abruptly with the loss of importance of towns like Cyrene and Leptis Magna.

There are evident differences in the history of the coastal regions of Tripolitania and Cyrenaica, which were under the influence and domination of the Roman Empire, and the vast deserted lands to their south. There are less apparent but still important differences in the respective history of Tripolitania and Cirenaica. For instance, Cyrene and Apollonia, its harbour, were at the very border of the Eastern Roman Empire (4th century), while Tripoli and the surrounding region were part of the Western Roman Empire. After the Arab conquest of both regions in 642, Cyrenaica did not regain its prior importance. During the Arab domination, Tripoli, born from the ashes of the three «poleis» of Oea, Sabratha and Leptis Magna, maintained its role as capital, but always as junior of the main capitals of the neighbouring states, e.g., Algiers and Tunis.

The period between the 5th and the 15th century is less known about for the territory of modern Libya. Historical records on this period have to be looked for mainly and specifically in medieval Arab sources. This will require ad hoc expertise and a dedicated feasibility study, which is out of the scope of this paper.

The situation changes, for the better in terms of availability of information, during the Modern Age, when the contacts between the North African countries, and the rest of the European and Mediterranean states, increase.

What follow are some hints at a possible investigation strategy, oriented towards European depositories, mainly inspired by the exhaustive contribution by Bono (1982) on western sources on four centuries of the history of Libya (1510-1911). Bono's essay describes the main features of the history and historiography of Tripoli in its relationships with the whole of Libya, presenting the general 20th century treatises on the whole country, and then detailing less important contributions on its geography or very specific themes. The book develops according to a possible periodisation of the history of Libya, subdivided into the short domina- tions of the Spanish and the Knights of Malta (1510-1551), the first Turkish period from 1552 to 1835 , with special attention on the age of Qarama-nli- (1711-1835), and the second Turkish period (1835-1911).

Unpublished and unexplored sources are thus described in their potential and documentary typology as available in the Libyan archives (based on surveys carried out by Bono himself in the mid 20th century), but mainly in those pertaining to the governments and trading companies of great and small European countries that, between the early 16th and mid 19th century, had to deal and compromise with the Barbary States, as Morocco, Algeria, Tunisia and Libya were commonly named at that time. In terms of documentary production and survival to our days, records of these exchanges can be found at the State Archives of many Italian regional states (e.g., Genova, Venezia, Parma, Napoli, Modena, Palermo, Milano, Firenze, Cagliari), at the French Archives Nationales (Paris and Nantes, France), at the Arquivo General of the Spanish Crown (Simancas, Spain), at the National Archives of Malta (La Valletta, Malta), at the Secret Vatican Archives (Roma, Italy), at the National Archives of the United Kingdom (Kew, U.K.), and at the Haus-, Hofund Staatsarchiv (Vienna, Austria). The most important typology of documents emerging as potentially including evidence of earthquake effects is the diplomatic and consular correspondence. This material mostly concerns Tripolitania and occasionally embraces the entire coastal area of Libya.

In the period 1835-1911, the documentation increases due to the reports produced by geographical and explorative surveys, including the vast Libyan Desert. The 20th century westerners' interest towards Libya was in a sense guided further by the Italian colonialist attitude, starting with sparse settlements in Tripolitania in late 19th century, and developing into an occupation of Libya in the period between 1911 and the end of WW II. The documents on Libyan affairs produced in this period are mainly stored in the Historical and Diplomatic Archive of the Italian Ministry of Foreign Affairs (Roma). 


\section{Conclusions}

Libya is not usually thought of as a seismically active country; however, a number of earthquakes are reported to have occurred in Libya including a major earthquake of $M=7.1$ on 19 April 1935. The recorded number of earthquakes in Libya is not representative of the actual total number because of the small number of seismological stations in the area and the limitations on instrumental sensitivity before 1950 , as well as the lack of seismological stations in Libya itself. The data on historical earthquakes are therefore of crucial importance.

Epicentral locations for the period 19352001 (Suleiman et al., 2001) strongly suggest that most of the activity is clustered in two areas: the NNW trending Hun Graben and the Al Jabal Al Akhdar to the northeast of Libya. The Hun Graben is a prominent rift valley feature trending NNW from the city of Hun to the city of Al Qaddahia. The boundary faults of the graben are marked by escarpments and substantial fault displacement can be mapped at the surface. Seismic activity seems to be concentrated along the eastern side of the graben. After the earthquake sequence in 1935, it was the site of a number of earthquakes in 1941, 2000, and 2001. The Brace (known now as Al-Maraj) earthquake in 1963 and other tremors recorded in Al Jabal Al Akhdar area NE Libya suggest that the area is still tectonically active.

The review presented above shows that the gaps in the information on historical seismicity of Libya before 1900 are so large that there is no confirmation that $i$ ) the two areas mentioned above were active in the past centuries as well or, in contrast, that ii) no other areas have to be considered when assessing seismic hazard for the territory of Libya.

To improve actual knowledge of long-term seismicity of Libya, some suggestions on potential sources to be explored were given. We would like the short list proposed to focus the researchers' attention, not only on their existence, but particularly on that their geographical distribution is a primary reason to implement an international collaboration aimed at improving today's knowledge on historical earthquakes that affected Libya.

\section{REFERENCES}

Agamennone, G. (1935): Notizie sismiche, Boll. Soc. Sismol. Ital., Roma, XXXIII (3-4), 146-151.

AMBRASEYS, N.N. (1984): Material for the investigation of the seismicity of Tripolitania (Libya), Boll. Geof. Teor. Appl., 26, 143-153.

AMBRASEYS, N.N. (1994): Material for the investigation of the seismicity of Libya, Libyan Studies, 25, 7-22.

Ambraseys, N.N., C.P. MELVILLE and R.D. Adams (1994): The Seismicity of Egypt, Arabia and the Red Sea. A Historical Review (Cambridge University Press, Cambridge), pp. 181.

ANONYMous (1685): Distinto ragguaglio gionto per lettera particolare ad un mercante nel Porto d'Ancona, Tripoli li 16 Maggio 1685, in Roma e Bologna, pp. 4.

ANONYMous (1884): Terremoto nell'oasi di Ghadàmes, Boll. Soc. Geogr. Ital., a. XVIII, v. XXI, s. II, v. IX, p. 169.

BACCHIELli, L. (1995): A Cyrenaica earthquake post 364 A.D.: written sources and archaeological evidences, Ann. Geofis., XXXVIII (5-6), 977-982.

Bono, S. (1982): Storiografia e fonti occidentali sulla Libia (1510-1911), Quaderni dell'Istituto italiano di cultura di Tripoli, Nuova Serie (L'Erma di Bretschneider, Roma), pp. 142.

Cavasino, A. (1927): Macrosismi avvertiti in Italia e Colonie nell'anno 1926, Boll. Soc. Sismol. It., Roma, vol. XXVI - 1926, pp. 25-34.

Cavasino, A. (1937): Macrosismi, Fasc. II, Bollettino Sismico Anno 1935, R. Ufficio Centrale di Meteorologia e Geofisica, Roma, pp. 7-16.

Corriere della Sera (1935a-c): a) 20 aprile; b) 23 aprile; c) 30 aprile, Milano.

Dresdnissche Geleherte Anzeigen (1756), Dresden.

Di ViTA, A. (1995): Archaeologists and earthquakes: the case of 365 A.D., Ann. Geofis., XXXVIII (5-6), 971976.

Guidoboni, E. (Editor) (1989): I Terremoti Prima del Mille in Italia e nell'Area Mediterranea: Storia, Archeologia, Sismologia (ING, Roma-SGA, Bologna), pp. 765.

Guidoboni E., A. Comastri and G. Traina (1994): Catalogue of the Ancient Earthquakes in the Mediterranean Area up to the 10th Century (ING, Roma-SGA, Bologna), pp. 504.

HofF, K.E.A. vON (1840): Chronik der Erdbeben und Vulkan Ausbrüche, I. Theil, (Justus Perthes, Gotha), pp. 470.

IngraO, G. (1930): Italia; Colonia, Macrosismi, Fasc. II, Bollettino Sismico Anno 1926, R. Ufficio Centrale di Meteorologia e Geofisica, Roma, 5-18; 19-21.

Minutilli, F. (1903): Bibliografia della Libia (Bocca, Torino), pp. 136.

Polidori R., A. Di Vita, G. Di Vita Evrard and L. BaCCHIELLI (1999): Libya the lost cities of the Roman Empire (Könemann, Cologne), pp. 256.

SIEBERG, A. (1932a): Die Erdbeben, in Handbuch der Geophysik, edited by B. GUTENBERG (Berlin), vol. IV.

SIEBERG, A. (1932b): Untersuchungen über Erdbeben und Bruchschollenbau im Östlichen Mittelmeergebeit, Denkschr. Medizin.-Natürwiss. Ges., Jena, 18 (2), 161-273.

STIROS, S.C. (2001): The A.D. 365 Crete earthquake and possible seismic clustering during the fourth to sixth centuries A.D. in the Eastern Mediterranean: a review 
of historical and archaeological data, J. Struct. Geol., 23 (2-3), 545-562.

SUleiman, A.S and D.I. Doser (1995): The seismicity, seismotectonics and earthquake hazards of Libya, with detailed analysis of the 1935 April $19, M=7.1$ earthquake sequence, Geophys. J. Int., 120, 312-322. Suleiman, A.S., I. DABA and E. AbDURAZAG (2001): Seismicity of Sirt and surrounding areas. Deatailed investigations and future planning, in First Conference on the Natural Resources in the Sirt Area, Sirt, Libya, pp. 13 (in Arabic). 